Wilfrid Laurier University

Scholars Commons @ Laurier

Geography and Environmental Studies Faculty

Publications

Geography and Environmental Studies

$8-1-2003$

\title{
Seasonality in the Surface Energy Balance of Tundra in the Lower Mackenzie River Basin
}

\author{
Wayne R. Rouse \\ McMaster University \\ Andrea K. Eaton \\ McMaster University \\ Richard M. Petrone \\ Wilfrid Laurier University, rpetrone@wlu.ca \\ L. Dale Boudreau \\ Environment Canada \\ Philip Marsh \\ Environment Canada
}

See next page for additional authors

Follow this and additional works at: https://scholars.wlu.ca/geog_faculty

\section{Recommended Citation}

Rouse, Wayne R.; Eaton, Andrea K.; Petrone, Richard M.; Boudreau, L. Dale; Marsh, Philip; and Griffis, Timothy J., "Seasonality in the Surface Energy Balance of Tundra in the Lower Mackenzie River Basin" (2003). Geography and Environmental Studies Faculty Publications. 18.

https://scholars.wlu.ca/geog_faculty/18

This Article is brought to you for free and open access by the Geography and Environmental Studies at Scholars Commons @ Laurier. It has been accepted for inclusion in Geography and Environmental Studies Faculty Publications by an authorized administrator of Scholars Commons @ Laurier. For more information, please contact scholarscommons@wlu.ca. 


\section{Authors}

Wayne R. Rouse, Andrea K. Eaton, Richard M. Petrone, L. Dale Boudreau, Philip Marsh, and Timothy J. Griffis 


\title{
Seasonality in the Surface Energy Balance of Tundra in the Lower Mackenzie River Basin
}

\author{
Wayne R. Rouse And Andrea K. EAton \\ School of Geography and Geology, McMaster University, Hamilton, Ontario, Canada \\ Richard M. Petrone \\ Department of Geography, Wilfred Laurier University, Waterloo, Ontario, Canada \\ L. DALe Boudreau \\ Meteorological Service of Canada, Environment Canada, Toronto, Ontario, Canada \\ PHILIP MARSH \\ National Water Research Institute, Environment Canada, Saskatoon, Saskatchewan, Canada \\ TIMOTHY J. GRIFFIS \\ Department of Soil, Water and Climate, University of Minnesota, St. Paul, Minnesota
}

(Manuscript received 26 September 2002, in final form 21 March 2003)

ABSTRACT

\begin{abstract}
This study details seasonal characteristics in the annual surface energy balance of upland and lowland tundra during the 1998-99 water year (Y2). It contrasts the results with the 1997-98 water year (Y1) and relates the findings to the climatic normals for the lower Mackenzie River basin region. Both years were much warmer than the long-term average, with Y1 being both warmer and wetter than Y2. Six seasons are defined as early winter, midwinter, late winter, spring, summer, and fall. The most rapid changes in the surface energy balance occur in spring, fall, and late winter. Of these, spring is the most dynamic, and there is distinct asymmetry between rates of change in spring and those in fall. Rates of change of potential insolation (extraterrestrial solar radiation) in late winter, spring, and fall are within $10 \%$ of one another, being highest in late winter and smallest in spring. Rates of change in air temperature and ground temperature are twice as large in spring as in fall and late winter, when they are about the same. Rates of change in components of the energy balance in spring are twice and 4 times as large as in fall and late winter, respectively. The timing of snowpack ripening and snowmelt is the major agent determining the magnitude of asymmetry between fall and spring. This timing is a result of interaction between the solar cycle, air temperature, and snowpack longevity. Based on evidence from this study, potential surface responses to a $1{ }^{\circ} \mathrm{C}$ increase in air temperature are small to moderate in most seasons, but are large in spring when increases range from $7 \%$ to $10 \%$ of average surface energy fluxes.
\end{abstract}

\section{Introduction}

The landscape of the lower Mackenzie River basin grades from open subarctic forest into open tundra that stretches to the coast of the Beaufort Sea. This tundra is undulating, consisting of sphagnum-dominated tussock tundra with a few shallow lakes in the lowlands, and shrub birch and sedge-lichen heath in the uplands. This study exploits a continuous two water year dataset

Corresponding author address: Wayne R. Rouse, School of Geography and Geology, McMaster University BSB 311, Hamilton, ON L8S 4K1, Canada.

E-mail: rouse@mcmaster.ca to document the seasonality in the surface energy balance of this tundra region and investigate the dynamics of the seasons as they differ between years and between lowland and upland sites.

The flux measurements were pursued in the Trail Valley Creek (TVC) basin $\left(68^{\circ} 45^{\prime} \mathrm{N}, 133^{\circ} 32^{\prime} \mathrm{W}\right)$, which is located $45 \mathrm{~km}$ northeast of Inuvik, Northern Territories, Canada, and feeds the lower Mackenzie River. Three prior studies have examined the summertime energy balance at these sites. Petrone et al. (2000) and Petrone and Rouse (2000) compared the surface energy fluxes at TVC with a wetland site in the Hudson Bay Lowland, and related their surface energy balances to synoptic 
weather types, while Eaton et al. (2001) examined energy balances of the upland and lowland sites as members of a suite of subarctic terrain types.

\section{Study sites and methods}

The predominant terrain type at TVC is open tundra that covers approximately $90 \%$ of the landscape, and is underlaid by continuous permafrost. The two adjacent sites represent typical lowland and upland tundra areas within the basin. Their height difference is $50 \mathrm{~m}$. Lowland soil comprises mineral soil tussocks, with peat in the intertussock hollows in a landscape often designated as tussock tundra. Sedges growing on the tussocks are the main vascular plants, and a 20-25-cm-deep Sphagnum mat dominates the intertussock hollows (Petrone et al. 2000). Upland soils are primarily mineral. Scrub birch is the dominant vascular plant and covers approximately $70 \%$ of the surface area. The birch canopy is underlain by a lichen heath mat. Lowland and upland sites are very moist, with average summer volumetric soil moisture in the surface layer of $55 \%$ and $34 \%$, respectively. Extrapolation of the ground temperature profiles to depth indicates maximum permafrost depths in lowlands and uplands at 0.60 and $0.91 \mathrm{~m}$ in the 199798 water year, (Y1) and 0.55 and $0.83 \mathrm{~m}$ in the 1998 99 water year (Y2).

The surface energy balance at both sites is described by

$$
Q^{*}=Q_{G}+Q_{H}+Q_{E}+Q_{M},
$$

where $Q^{*}$ is net radiation, $Q_{G}$ is the ground heat flux, $Q_{H}$ is the sensible heat flux, $Q_{E}$ is the latent heat flux, and $Q_{M}$ is the latent heat of fusion involved in the snowmelt process. When directed away from the surface $Q_{G}$, $Q_{H}$ and $Q_{E}$ are positive, and $Q_{M}$ is positive when latent heat is utilized during the melt process in spring. The combined $Q_{E}+Q_{M}$ is referred to as the combined latent heat flux in this paper.

Instrumentation is identical at both sites. The $Q^{*}$ is measured using Radiation and Energy Balance Systems (REBS) net radiometers mounted $3.2 \mathrm{~m}$ above the ground surface; $Q_{G}$ is determined from heat flux transducers (Middleton). These were buried immediately below the surface and represent an average of hummock and hollow measurements at the lowland site, and birch shrub and lichen dominated microsites at the upland. The flux measurements were checked against calorimetric calculations (Rouse 1984; Halliwell and Rouse 1987) during the period of ground thaw. In Y1 the transducer measurements gave values $2 \%$ less than the calorimetric calculation, and in Y2 values were $19 \%$ greater. The measured flux values were judged as being most acceptable because underestimation, not overestimation, by heat flux transducers proved the problem in previous studies referenced above. The sensible heat flux $Q_{H}$ is determined using the eddy correlation method, in which its mean vertical flux is obtained from

$$
Q_{H}=\rho C_{p} \overline{w^{\prime} T_{a}^{\prime}}
$$

where $\rho$ is the mean density of air, $C_{p}$ is the specific heat capacity of air, and $w^{\prime}$ and $T_{a}^{\prime}$ are vertical wind speed and air temperature, respectively. The primes indicate the differences between instantaneous and mean values, and the overbar indicates an averaging operation. The covariance of $w$ and $T_{a}$ is $w^{\prime} T_{a}^{\prime}$. The averaging interval is $30 \mathrm{~min}$. R. M. Young vertical propeller anemometers are used to measure $w$, and $T_{a}$ is measured using fine-wire chromel-constantan thermocouples. These instruments are mounted at a height of $3.2 \mathrm{~m}$. Vertical propeller anemometers stall at low wind speeds, resulting in a consistent underestimation of $Q_{H}$ when they are used to measure $w$ (Brutsaert 1982; Blanford and Gay 1992). To compensate for this, a frequency response correction factor (Moore 1986; Blanford and Gay 1992) of 1.29 is applied at each site. This value falls in the midrange of correction factors calculated for similar eddy correlation systems in other studies (Tsvang et al. 1973; McNeil and Shuttleworth 1975; Moore 1976; Spittlehouse and Black 1979; Blanford and Gay 1992; Petrone et al. 2000). This instrumentation proved robust through the long arctic winters and gave relatively continuous datasets. The reliability of the winter data is less than its summer counterpart, primarily because of inaccuracies in measuring $Q^{*}$ during the polar night with unattended net radiometers. In Eq. (1), $Q_{E}+Q_{M}$ is calculated as a residual.

Other instrumentation at the research sites includes chromel-constantan thermocouples to measure ground temperatures $\left(T_{g}\right)$ buried at depths $0.0,0.02,0.05,0.10$, $0.15,0.25,0.35$, and $0.45 \mathrm{~m}$, and Campbell Scientific TDR probes to measure volumetric soil moisture content. The latter were installed vertically and sensed the integrated soil moisture through the depth interval $0.1-$ $0.4 \mathrm{~m}$ beneath the surface.

\section{Results and discussion}

\section{a. Comparative temperature, precipitation, and climate normals}

Winters are cold and long, and summers are cool and short at TVC, which is typical of the high subarctic environment (Fig. 1). Air temperatures range from $-40^{\circ}$ to $+20^{\circ} \mathrm{C}$, rainfall events are numerous and usually small, and most snow accumulates in early and late winter. Average temperatures at TVC are approximately $4^{\circ} \mathrm{C}$ less than at the Inuvik weather station, $45 \mathrm{~km}$ to the south. Summer rainfall is similar to that at Inuvik for both Y1 and Y2. Snow accumulation measured on the upland at TVC shows similar depth (peak accumulations between 400 and $500 \mathrm{~mm}$ ) and longevity (about 7.5 months) each year. At Inuvik, Y1 and Y2 are $4.3^{\circ}$ and $2.0^{\circ} \mathrm{C}$ warmer, respectively, than the 44-yr longterm average. They represent the second and sixth warmest years in the 44-yr record. Precipitation at TVC in $\mathrm{Y} 1$ is $85 \%$ greater than the long-term average at 


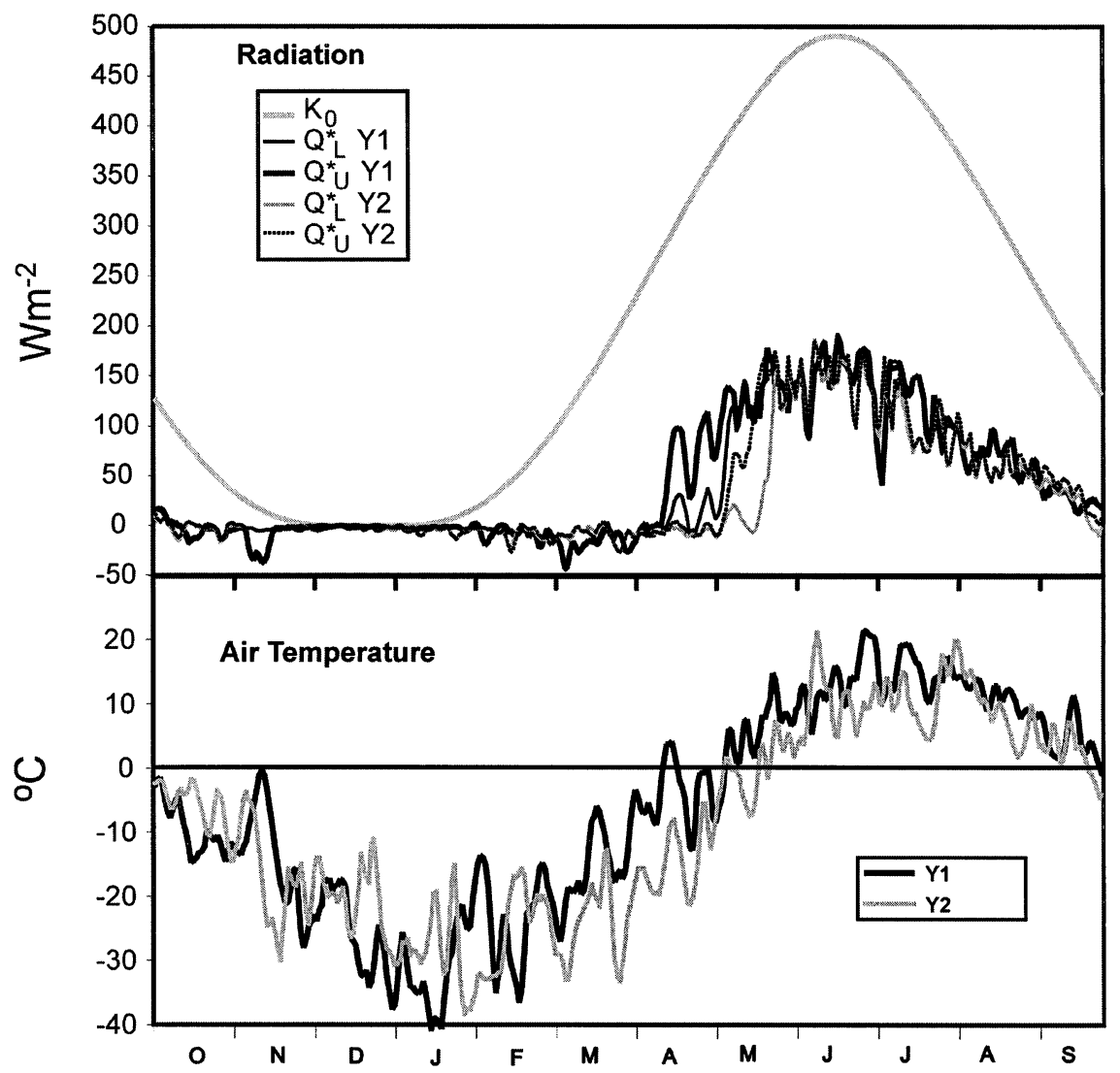

FIG. 1. Potential insolation, $K_{0}$, net radiation, $Q^{*}$, and air temperature for $\mathrm{Y} 1$ and $\mathrm{Y} 2$, and for lowland (L) and upland (U) sites.

Inuvik, but in $\mathrm{Y} 2$ is very close to average. The two water years studied occur during a decade that has witnessed a substantial warming in the Mackenzie basin (Stewart et al. 1998; Rouse et al. 2003), with Y1 being warmer and wetter than Y2.

\section{b. The seasons}

The analysis in this paper focuses on the seasons (Table 1). As defined, the seasons apply to the tundra of the lower Mackenzie River valley, and are based on potential insolation (extraterrestrial solar radiation), $K_{0}$, air temperature, $T_{a}$, and snow cover. The dates separating fall and early winter are very close to those separating hydrological water years. The start of early winter coincides with the establishment of the seasonal snowpack, which also coincides with average daily $T_{a}$ $<0$. Early winter persists through to the winter solstice. For 43 days between 30 November and 13 January $K_{\phi}$ $=\phi$. Midwinter extends from the winter solstice to spring equinox. This is the coldest period of the year with little snowfall and a stable snowpack. During late winter, temperatures warm at an increasing rate, and the snowpack begins to ripen. Spring is the period of snowmelt. It begins in early May, when daytime temperatures first warm above freezing and solar radiation becomes an important melting agent. Melt becomes rapid when average daily $T_{a}>0$. Final snowmelt occurs around the beginning of June and marks the transition into summer. Summer and midwinter seasons are of equal length (Table 1). The transition from summer into fall is not particularly distinctive. At the transition, $K_{0}$ has fallen to one-quarter of its magnitude at the summer solstice (Fig. 1) and it is a time of plant senescence and cooling ground temperatures. As noted above, the end of the fall season coincides with the establishment of the permanent snowpack.

\section{c. Seasonal patterns}

Seasonal patterns in rates of change in air temperature, ground temperature, potential insolation, and the energy balance components are distinctive (Fig. 1). After $K_{0}$ and $T_{a}$ start an in-phase increase in mid-January, there is a 3-4-month lag before a noteworth increase in $Q^{*}$ is observed. The length of this lag varies between years and sites. After the summer solstice, $K_{0}$ and $Q^{*}$ decrease in phase, but there is more than a 1-month lag before $T_{a}$ begins to decrease. Thus, $Q^{*}$ and $T_{a}$ behave asynchronously to one another. The former experiences a long lag behind increasing $K_{0}$ in midwinter through spring, but none in the summer, and the latter experi- 
TABLE 1. Rates of change in air temperatures, $T_{a}$, ground temperatures at $10 \mathrm{~cm}, T_{g}$, potential insolation, $K_{0}$, net radiation, $Q^{*}$, ground heat flux, $Q_{G}$, sensible heat flux, $Q_{H}$, and latent heat fluxes, $\left(Q_{E}+Q_{M}\right)$, respectively. Results are averaged for upland and lowland sites, and Y1 and Y2 refer to the water years 1997-98 and 1998-99. Temperature changes are in $\left({ }^{\circ} \mathrm{C}\right.$ day $\left.{ }^{-1}\right)$ and flux changes in $\left(\mathrm{W}\right.$ m ${ }^{-2}$ day $\left.{ }^{-1}\right)$. The summary averages the results for the $2 \mathrm{yr}$.

\begin{tabular}{|c|c|c|c|c|c|c|}
\hline & Early winter & Midwinter & Late winter & Spring & Summer & Fall \\
\hline $\begin{array}{l}\text { Dates } \\
\text { Days }\end{array}$ & $\begin{array}{c}3 \text { Oct-21 Dec } \\
80\end{array}$ & $\begin{array}{c}22 \text { Dec-21 Mar } \\
90\end{array}$ & $\begin{array}{c}22 \mathrm{Mar}-30 \mathrm{Apr} \\
40\end{array}$ & $\begin{array}{c}1 \text { May-30 May } \\
30\end{array}$ & $\begin{array}{c}31 \text { May-28 Aug } \\
90\end{array}$ & $\begin{array}{c}29 \text { Aug-2 Oct } \\
35\end{array}$ \\
\hline $\begin{array}{l}T_{a} \mathrm{Y} 1 \\
T_{a} \mathrm{Y} 2 \\
T_{g} \mathrm{Y} 1 \\
T_{g} \mathrm{Y} 2 \\
K_{o} \\
Q^{*} \mathrm{Y} 1 \\
Q^{*} \mathrm{Y} 2 \\
Q_{G} \mathrm{Y} 1 \\
Q_{G} \mathrm{Y} 2 \\
Q_{H} \mathrm{Y} 1 \\
Q_{H} \mathrm{Y} 2 \\
\left(Q_{E}+Q_{M}\right) \mathrm{Y} 1 \\
\left(Q_{E}+Q_{M}\right) \mathrm{Y} 2\end{array}$ & $\begin{array}{l}-0.39 \\
-0.19 \\
-0.14 \\
-0.10 \\
-1.44 \\
-0.24 \\
-0.27 \\
-0.06 \\
-0.09 \\
-0.03 \\
-0.03 \\
-0.15 \\
-0.15\end{array}$ & $\begin{array}{r}0.31 \\
-0.04 \\
0.00 \\
-0.07 \\
1.78 \\
-0.14 \\
-0.01 \\
0.07 \\
0.06 \\
-0.08 \\
0.05 \\
-0.14 \\
-0.12\end{array}$ & $\begin{array}{r}0.15 \\
0.30 \\
0.26 \\
0.06 \\
4.58 \\
1.91 \\
-0.33 \\
0.08 \\
0.05 \\
0.67 \\
-0.13 \\
1.06 \\
-0.24\end{array}$ & $\begin{array}{l}0.27 \\
0.45 \\
0.18 \\
0.42 \\
3.80 \\
3.14 \\
5.20 \\
0.47 \\
0.99 \\
1.43 \\
1.80 \\
1.24 \\
2.41\end{array}$ & $\begin{array}{r}0.04 \\
-0.01 \\
0.04 \\
0.02 \\
-2.34 \\
-0.79 \\
-0.85 \\
-0.15 \\
-0.31 \\
-0.52 \\
-0.31 \\
-0.12 \\
-0.23\end{array}$ & $\begin{array}{l}-0.35 \\
-0.14 \\
-0.23 \\
-0.07 \\
-4.31 \\
-2.13 \\
-2.06 \\
-0.13 \\
-0.17 \\
-0.43 \\
-0.95 \\
-1.57 \\
-0.94\end{array}$ \\
\hline & & LARGE & nmary of rates of & lange & SMALL & \\
\hline $\begin{array}{l}T_{a} \\
T_{g} \\
K_{o} \\
Q^{*} \\
Q_{G} \\
Q_{H} \\
\left(Q_{E}+Q_{M}\right)\end{array}$ & \multicolumn{6}{|c|}{$\begin{array}{l}\text { Spring }>\text { early winter }>\text { fall }>\text { late winter }>\text { midwinter }>\text { summer } \\
\text { Spring }>\text { late winter }>\text { fall }>\text { early winter }>\text { midwinter }>\text { summer } \\
\text { Late winter }>\text { fall }>\text { spring }>\text { summer }>\text { midwinter }>\text { early winter } \\
\text { Spring }>\text { fall }>\text { late winter }>\text { summer }>\text { midwinter }>\text { early winter } \\
\text { Spring }>\text { fall }>\text { late winter }>\text { summer }>\text { midwinter }>\text { early winter } \\
\text { Spring }>\text { fall }>\text { late winter }>\text { summer }>\text { midwinter }>\text { early winter } \\
\text { Spring }>\text { fall }>\text { late winter }>\text { summer }>\text { early winter }>\text { midwinter }\end{array}$} \\
\hline
\end{tabular}

ences a lag in summer, but little from midwinter through spring. In fall, $K_{0}, Q^{*}$, and $T_{a}$ decrease in phase. Components of the surface energy balance (Fig. 2) are positive in spring, summer, and fall (155 days), and are mainly negative in early and midwinter (170 days), although some sublimation is indicated. In late winter they may be either positive or negative, depending on the year. The largest differences in magnitude between Y1 and $\mathrm{Y} 2$ occur in late winter and spring, and only small year-to-year differences are evident in other seasons (Fig. 2). On an annual basis the fluxes in $\mathrm{Y} 2$ are from $70 \%$ to $90 \%$ of those in $\mathrm{Y} 1$.

\section{d. Seasonal rates of change}

Table 1 indicates that rates of change in $K_{0}$ are largest in late winter, fall, and spring and are smallest in summer, midwinter, and early winter. For $T_{a}$, however, rates of change are largest in late spring, early winter, and fall, and are smallest in early winter, midwinter, and summer. Spring, fall, and late winter are the most dynamic and significant seasons in terms of rates of change in ground temperatures and all components of the energy balance. There is asymmetry in their dynamics. Rates of change in $T_{a}$ and $T_{g}$ are twice as large in spring as in fall and late winter, when they are about the same. Rates of change in components of the energy balance in spring are twice and 4 times as large as in fall and late winter, respectively.

Warming extends from spring into late winter because the seasonal snowpack ripens and melts earlier, and warming extends the fall season into early winter because the seasonal snowpack forms later. These effects are reversed with cooling. The snowpack plays a number of roles. Through its high albedo, it minimizes the absorbed solar radiation and the energy available for surface and subsurface heat fluxes. It also ties up water in a solid form, thereby reducing the source for evaporation. However, sublimation can, and does, occur. The snowpack blankets the ground from subsurface heat loss in winter, and utilizes substantial amounts of heat energy in the melt process. All of these effects are seen in the results of this study.

Most important is the interaction of air temperature, snowpack, and solar radiation in late winter and spring. The large lag between increasing potential insolation and increasing net radiation was noted earlier in this report. It is due to the persistence of the high-albedo snowpack. When temperatures rise above freezing, the snowpack ripens and starts to melt, and as melting proceeds the rate accelerates. As a result, the decrease in surface albedo during melt is nonlinear, becoming more rapid as bare patches enlarge (Marsh et al. 1997). The net radiation increases rapidly, ground thaw is accelerated, and the ground, sensible, and latent heat fluxes become substantial. This is illustrated clearly in Fig. 2. Regional climate warming hastens this process and cooling retards it. A shallow snowpack speeds the process and a deep one slows it.

Relationships in fall are not analogous. As noted ear- 


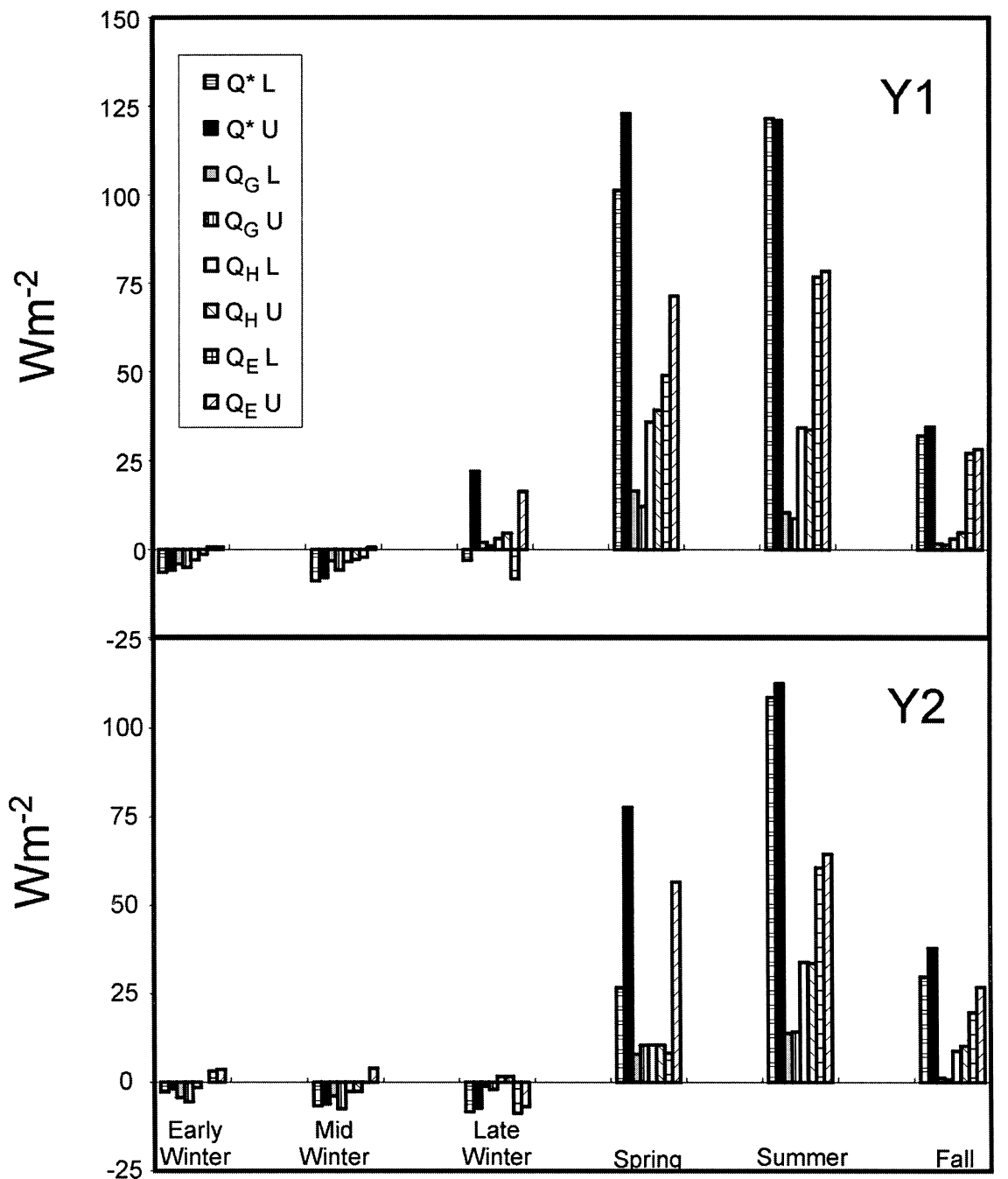

FIG. 2. Seasonal energy balances for Y1 and Y2 and for lowland (L) and upland (U) sites; $Q^{*}$ is net radiation, $Q_{G}$ is ground heat flux, $Q_{H}$ is sensible heat flux, and $Q_{E}+Q_{M}$ is combined latent heat fluxes.

lier, the rates of decrease in $K_{0}, Q^{*}$, and $T_{a}$ are in phase, and are similar for both years (Fig. 1) in spite of the fact that the temperature in the fall of $\mathrm{Y} 1$ was $2.5^{\circ} \mathrm{C}$ higher than in Y2. By definition, fall ends prior to the establishment of the winter snowpack. Even if the establishment of the snowpack is delayed into early winter, due to warmer conditions, the increase in absorbed solar radiation will be small because $K_{0}$ becomes increasingly smaller after the fall equinox (Fig. 1). Similarly, if the snowpack is established earlier, the decrease in absorbed solar radiation will be relatively small.

The above discussion implies that potential effects of climate warming or cooling on the surface energy balance of high-latitude tundra should be largest in spring. One can quantify this per unit of temperature increase (Table 2). Based on measured differences between Y1 and $\mathrm{Y} 2$ (Fig. 1), a $1{ }^{\circ} \mathrm{C}$ increase in temperature indicates that responses in the component fluxes of the energy balance are small in late winter, moderate in fall and early winter, midwinter, and summer, and large in spring, which shows increases from $7 \%$ to $10 \%$ over the average flux magnitudes.

Some of the implications of earlier snowmelt in spring are as follows. Larger $Q^{*}$ during warm years promotes earlier ponding at the surface. Earlier ground thaw allows evergreen shrub roots to tap into soil water, and promotes earlier leafing of the deciduous shrubs and trees, both of which are factors allowing transpiration to commence. Measurements of $Q_{E}$ from low-flying aircraft over tundra and open coniferous forest substantiate the latter. Evapotranspiration is small when soils are still frozen, but increases dramatically after thawing (Schuepp et al. 2001). There is also convincing evidence that an early spring enhances carbon fixation and dry matter production throughout the subsequent growing season (Griffis et al. 2000). 
TABle 2. Potential responses to an increase of $1{ }^{\circ} \mathrm{C}$ in air temperature as indicate from differences in the $\mathrm{Y} 1$ and $\mathrm{Y} 2$ results of this study; $\Delta Q^{*}, \Delta Q_{G}, \Delta Q_{H}$; and $\Delta\left(Q_{E}+Q_{M}\right)$ denote changes in net radiation, ground heat flux, sensible heat flux, combined latent heat fluxes (W $\mathrm{m}^{-2}$ ) and ground temperature at $10 \mathrm{~cm}\left({ }^{\circ} \mathrm{C}\right)$. AVE is the average seasonal value of the parameter for the $2 \mathrm{yr}$ of measurement and the two sites.

\begin{tabular}{|c|c|c|c|c|c|c|}
\hline & Early winter & Midwinter & Late winter & Spring & Summer & Fall \\
\hline$\Delta Q^{*}$ & 1.8 & 1.1 & 0.2 & 7.0 & 2.1 & 1.0 \\
\hline$Q^{*} \mathrm{AVE}$ & -4.0 & -7.3 & 1.1 & 94.9 & 116.9 & 35.6 \\
\hline$\Delta Q_{G}$ & -0.1 & -0.3 & 0.1 & 0.8 & -0.6 & 0.2 \\
\hline$Q_{G} \mathrm{AVE}$ & -5.1 & -6.0 & -0.2 & 12.4 & 12.0 & 1.2 \\
\hline$\Delta Q_{H}$ & 0.7 & 0.4 & 0.1 & 2.4 & 0.0 & -0.1 \\
\hline$Q_{H} \mathrm{AVE}$ & -1.1 & -2.9 & 2.7 & 24.0 & 33.8 & 8.5 \\
\hline$\Delta\left(Q_{E}+Q_{M}\right)$ & 1.2 & 1.0 & 0.0 & 3.8 & 2.7 & 0.9 \\
\hline$\left(Q_{E}+Q_{M}\right)$ AVE & 2.1 & 1.6 & 0.0 & 58.4 & 71.1 & 25.9 \\
\hline
\end{tabular}

\section{Conclusions}

Allocating the surface climate into seasons is useful in helping understand rates of change in surface fluxes and ground temperature and sensitivity to regional temperature changes.

Potential insolation, net radiation, and air temperature frequently behave asymmetrically with one another. Net radiation experiences a long lag behind increasing potential insolation and air temperature in midwinter through spring, but none in summer. Air temperature experiences a lag in summer, but little from midwinter through spring. In fall, patterns of decrease in potential insolation, net radiation, and air temperature are in phase.

Fluxes are positive in spring, summer, and fall and are mainly negative in early and midwinter. In late winter, they may be either positive or negative, depending on the year and the site. In late winter and spring, there are large differences in magnitudes of the surface energy balance components between Y1 and Y2, but only small differences in the other seasons.

Spring, fall, and late winter are most significant in terms of seasonal rates of change and there is asymmetry in their dynamics. Rates of change in $T_{a}$ and $T_{g}$ are twice as large in spring as in fall and late winter. Rates of change in components of the energy balance are twice and 4 times as large in spring as in fall and late winter, respectively.

The spring shoulder season is potentially the most sensitive to regional warming or cooling because of the interaction between ripening and melting of the seasonal snowpack and the increasing solar radiation. With regional warming the snowpack starts melting earlier. As snowmelt proceeds, its rate accelerates, as do the increases in the magnitudes of absorbed solar radiation and net radiation. This enhances the rate of ground warming and the magnitude of the convective fluxes. A $1{ }^{\circ} \mathrm{C}$ increase in temperature in spring increases the surface energy fluxes from $7 \%$ to $10 \%$ of average values. This magnitude of increase is substantially greater than for the other seasons of the year.

Acknowledgments. Financial support for this project was provided by the Meteorological Service of Canada
(MSC) and Natural Science and Engineering Research Council of Canada (NSERC), through network research grants to the Mackenzie GEWEX Study, NSERC individual research grants, and student northern training grants from the Canada Department of Indian and Northern Affairs. Logistical support during the field measurement campaigns was provided by Aurora College and the Polar Continental Shelf Project. Inuvik weather data were provided from MSC, and facilitated with the help of Bob Kochtubajda and Patrick Kyle.

\section{REFERENCES}

Blanford, J. H., and L. W. Gay, 1992: Test of a robust eddy correlation system for sensible heat flux. Theor. Appl. Climatol., 40, 5360 .

Brutsaert, W., 1982: Evaporation into the Atmosphere. D. Reidel, $299 \mathrm{pp}$.

Eaton, A. K., W. R. Rouse, P. M. Lafleur, P. Marsh, and P. D. Blanken, 2001: Surface energy balance of the western and central Canadian subarctic: Variations in the energy balance among five major terrain types. J. Climate, 14, 3692-3703.

Griffis, T., W. R. Rouse, and M. Waddington, 2000: Interannual variability in the net $\mathrm{CO}_{2}$ exchange in a subarctic fen. Global Biogeochem. Cycles, 14, 1109-1121.

Halliwell, D. H., and W. R. Rouse, 1987: Soil heat flux in permafrost: Characteristics and accuracy of measurement. J. Climatol., 7, 571-584.

Marsh, P., J. W. Pomeroy, and N. Neumann, 1997: Sensible heat flux and local advection over a heterogenous landscape at an arctic tundra site during snowmelt. Ann. Glaciol., 25, 132-136.

McNeil, D. D., and W. J. Shuttleworth, 1975: Comparative measurements of the energy fluxes over a pine forest. Bound.-Layer Meteor., 9, 297-313.

Moore, C. J., 1976: Eddy flux measurements above a pine forest. Quart. J. Roy. Meteor. Soc., 102, 913-918.

- , 1986: Frequency response corrections for eddy correlation systems. Bound.-Layer Meteor., 37, 17-35.

Petrone, R., and W. R. Rouse, 2000: Synoptic controls on the surface energy and water budgets in subarctic regions of Canada. Int. J. Climatol., 20, 1149-1165.

$\_,-$_ , and P. Marsh, 2000: Comparative surface energy budgets in western and central subarctic regions of Canada. Int. J. Climatol., 20, 1131-1148.

Rouse, W. R., 1984: Microclimate at Arctic tree line 2. Soil microclimate of tundra and forest. Water Resour. Res., 20, 67-73.

—_, and Coauthors, 2003: Energy and water cycles in a high latitude, north-flowing river system: Summary of results from the Mackenzie GEWEX Study_Phase 1. Bull. Amer. Meteor. Soc., 84, 73-87.

Schuepp, P. H., I. J. MacPherson, C. Brown-Mitic, B. Nagarajan, and 
P. Yau, 2001: Airborne observations of surface-atmosphere energy exchange over the northern Mackenzie Basin. Proc. Sixth Scientific Workshop for the Mackenzie GEWEX Study, Saskatoon, SK, Canada, 27-37. [Available from MAGS Secretariat, NWRI, Saskatoon, SK S7N 3H5, Canada.]

Spittlehouse, D. L., and T. A. Black, 1979: Determination of forest evapotranspiration using Bowen ratio and eddy-correlation measurements. J. Appl. Meteor., 18, 647-653.
Stewart, R. E., and Coauthors, 1998: The Mackenzie GEWEX Study: The water and energy cycles of a major North American river system. Bull. Amer. Meteor. Soc., 79, 2665-2683.

Tsvang, L. R., B. M. Koprov, S. L. Zubkovskii, A. J. Dyer, B. Hicks, M. Miyake, R. W. Stewart, and J. W. McDonald, 1973: A comparison of turbulence measurements by different instruments: Tsimlyansk Field Experiment 1970. Bound.-Layer Meteor., 3, 499-521. 
Copyright $\odot 2003$ EBSCO Publishing 